\title{
Rumen microbial fermentation, protozoan abundance and boron availability in yearling rams fed diets with different boron concentrations
}

\author{
O. Sizmaz ${ }^{1,3}$, B.H. Koksal ${ }^{2}$ and G. Yildiz ${ }^{1}$ \\ ${ }^{1}$ University of Ankara, Faculty of Veterinary Medicine, Department for Animal Nutrition and Nutritional Diseases \\ 06110 Ankara, Turkey \\ ${ }^{2}$ University of Adnan Menderes, Faculty of Veterinary Medicine, Department for Animal Nutrition and Nutritional Diseases \\ 09016 Aydın, Turkey
}

KEY WORDS: boric acid, mineral, short chain fatty acids, rumen fluid, diet, rams

Received: $\quad 26$ July 2016

Revised: 6 December 2016

Accepted: 7 March 2017

${ }^{3}$ Corresponding author:

e-mail: ozgeabacioglu@gmail.com

\begin{abstract}
The objective of the in vivo study was to evaluate whether feeding graded levels of boron affect rumen microbial fermentation including $\mathrm{pH}$, ammonia, volatile fatty acids and protozoa counts. In the experiment 4 Merino rams in a $4 \times 4$ Latin square design fed forage and concentrate with boric acid $(0,200$, 300 and $400 \mathrm{mg} \cdot \mathrm{kg}^{-1}$ in control, B1, B2 and B3 group, respectively) were used. Each experimental period lasted 14 days, with 12 first days of diet adaptation. In comparison with control diet, boron supplementation did not increased the total volatile fatty acid concentration before and $3 \mathrm{~h}$ after feeding. However in both time points, acetate content was higher in B1 and B2 than in control and B3 groups, whereas propionate content was lower in all boron-supplemented groups. The iso-butyrate, $n$-butyrate and iso-valerate levels were influenced only $3 \mathrm{~h}$ after feeding. The $n$-valerate content was lower in B1 and B2 than in control and B3 groups. Protozoan abundance in the rumen fluid was significantly higher in animals fed B3 and control diets both before and after feeding. The boron content in rumen fluid was increased in boron-supplemented groups to average value $7.32 \mathrm{ppm}$, but dose effect was not observed. The obtained results showed that dietary boron supplementation had a dose-dependent influence on rumen microbial fermentation and protozoan abundance in yearling rams. However, the boron concentration in rumen fluid did not increased simultaneously with increased dose in a diet. Further studies are needed to estimate the most recommended dose of boron in the ruminant diets and to better understand the boron role in the processes occurring in the rumen.
\end{abstract}

\section{Introduction}

Such trace minerals as selenium, zinc and cobalt, are essential for various physiological functions in animals, and their deficiency may cause many disorders (Rozbicka-Wieczorek et al., 2016). Boron is also an important element which plays a great role in mineral metabolism, enzymes and some hormones actions (WHO, 1998). Multiple studies have been carried out to evaluate the utilization of boron in animal diets. It was shown that boron affects a variety of metabolic functions such as some enzymes activity, energy and lipid metabolism (Devirian and Volpe, 2003; Tanaka and Fujiwara, 
2008) and several haematological parameters in poultry (Yildiz et al., 2013; Çinar et al., 2015) and cattle (Kabu and Uyarlar, 2015), however, there is no information about the effects of boron on rumen fermentation and fauna such as bacteria and protozoa. The count of protozoa in rumen milieu is $10^{5}-10^{6} \cdot \mathrm{ml}^{-1}$ rumen fluid, which constitutes a large proportion of the rumen fauna; however protozoa role is still an area of substantial controversy.

Some trace minerals such as molybdenum and copper form complexes with solid rumen digesta including bacteria and protozoa (Allen and Gawthornet, 1987; Spears, 2003). Having this in mind, we hypothesized that the boron as a trace mineral might improve rumen microbial fermentation and protozoa abundance. Therefore, the aim of in vivo trial was to evaluate the influence of different boron concentrations on rumen fermentation and to possibly elucidate the underlying mechanism of boron action.

\section{Material and methods}

\section{Animals, diets, and experimental design}

Four 12-month-old Merino rams weighting approximately $60 \mathrm{~kg}$ were fed four different experimental diets (control - basal diet with $0 \mathrm{mg} \cdot \mathrm{kg}^{-1}$ boron, B1 - basal diet with $35 \mathrm{mg} \cdot \mathrm{kg}^{-1}$ boron, B2 - basal diet with $52.5 \mathrm{mg} \cdot \mathrm{kg}^{-1}$ boron, and B3 - basal diet with $70 \mathrm{mg} \cdot \mathrm{kg}^{-1}$ boron) in a $4 \times 4$ Latin square design. Rams were fed lucerne pellets $\left(500 \mathrm{~g} \cdot \mathrm{d}^{-1}\right)$, barley straw $\left(400 \mathrm{~g} \cdot \mathrm{d}^{-1}\right)$ and concentrates $\left(500 \mathrm{~g} \cdot \mathrm{d}^{-1}\right)$. Basal diet contained, \%: maize 25 , barley 24 , soyabean meal 3, sunflower meal 12, rasmol 25, full fat soya 2 , molasses $4, \mathrm{CaCO}_{3} 3$, salt 1 and mineralvitamin supplement 1 (Ekol A. S., Istanbul, Turkey) (mg $\cdot \mathrm{kg}^{-1}$ : retinol 3000 , cholecalciferol 75000 , tocopherol 30 000, thiamine 980, niacin 99 500, biotin 20, Mn 50 000, Zn 50 000, Fe 50 000, $\mathrm{Cu} 10$ 000, I 8000, Co 200, Se 300, Mg 250). Boric acid $\left(\mathrm{H}_{3} \mathrm{BO}_{3}\right.$; cat no. A0150965 032, Merck KGaA, Darmstadt, Germany) was used as a source of boron. Each animal was placed in an individual pen (area $24 \mathrm{~m}^{2}$ ) with ad libitum access to water. The feed was provided twice a day (9:00 and 16:30) and residues were available until the next feed. The nutrient composition and energy content of raw ingredients of feed materials and experimental diets (Table 1) were analysed according to AOAC methods (1995), whereas the metabolic energy levels were calculated according to the Turkish Standards Institute (TSE, 1991). The experimental area and equipment were disinfected prior to the study, and anticoccidial drugs (oxane and sulfametine) were
Table 1. Chemical composition and energy contents of forages and experimental diets with or without boron

\begin{tabular}{|c|c|c|c|c|c|c|}
\hline \multirow{2}{*}{ Indices } & \multicolumn{2}{|l|}{ Forages } & \multicolumn{4}{|c|}{ Experimental diet } \\
\hline & lucerne & straw & control & B1 & B2 & B3 \\
\hline Dry matter, $\%$ & 92.8 & 89.0 & 90.8 & 90.7 & 91.1 & 92.0 \\
\hline Organic matter, \% & 84.6 & 83.7 & 82.5 & 81.9 & 82.1 & 81.1 \\
\hline Crude protein, $\%$ & 9.5 & 2.7 & 15.0 & 15.9 & 15.7 & 16.5 \\
\hline Crude fat, $\%$ & 30.8 & 39.6 & 6.4 & 6.8 & 6.26 & 6.5 \\
\hline $\begin{array}{l}\text { Acid detergent } \\
\quad \text { fibre, } \%\end{array}$ & 46.0 & 51.0 & ND & ND & ND & ND \\
\hline Ether extract, \% & 1.10 & 2.18 & 4.20 & 4.16 & 4.01 & 3.96 \\
\hline $\begin{array}{l}\text { Metabolizable } \\
\quad \text { energy, } \mathrm{kcal} \cdot \mathrm{kg}^{-1}\end{array}$ & 1495 & 1168 & 2647 & 2616 & 2637 & 2595 \\
\hline Boron, $\mathrm{mg} \cdot \mathrm{kg}^{-1}$ & $39.1^{1}$ & $23.9^{1}$ & 10.2 & 42.5 & 61.7 & 80.1 \\
\hline
\end{tabular}

${ }^{1}$ values were reported by Serbester (2013); ND - not detected

administered twice during the study. The room temperature was $10-24{ }^{\circ} \mathrm{C}$, and ventilation was ensured by open doors and windows. All procedures were performed in accordance with the National Regulations for Animal Use in Research and approved by the local Ethics Committee of Ankara University for Animal Experiments (20071557).

\section{Faeces, rumen and blood sampling}

The experiment lasted 14 days and included 12 days of adaptation to the experimental diet and 2 days (days 13 and 14) of data collection. Rumen fluid was collected before $(0 \mathrm{~h})$ and $3 \mathrm{~h}$ after feeding $(3 \mathrm{~h})$ using a rumen probe. It was analysed for $\mathrm{pH}$ and ammonia concentration by using electrode. Protozoan abundance was measured as described by Ogimoto and Imai (1981) after fixation and staining with methyl-green formalin-saline solution $\left(0.6 \mathrm{~g} \cdot 1^{-1}\right.$ methyl green, $100 \mathrm{ml} \cdot 1^{-1} 37 \%$ formaldehyde and $\left.8.0 \mathrm{~g} \cdot 1^{-1} \mathrm{NaCl}\right)$. A part of the rumen fluid was frozen at $-20^{\circ} \mathrm{C}$ to determine the concentration of volatile fatty acids (VFA). Rumen fluid was centrifuged at $2218 \mathrm{~g}$ for $15 \mathrm{~min}$ at $4{ }^{\circ} \mathrm{C}$, and the supernatant was dissolved into two Eppendorf tubes with $1 \mathrm{ml}$ met-phosphoric acid solution $\left(100 \mathrm{~g} \cdot \mathrm{l}^{-1}\right)$. Subsequently, both tubes were centrifuged at $13150 \mathrm{~g}$ for $10 \mathrm{~min}$ at $4{ }^{\circ} \mathrm{C}$, and the obtained supernatant was used to analyse VFA with use of VFA standard (Supelco Volatile Free Acids Mix 46975-U; Sigma-Aldrich, St. Louis, MO, USA) by a Shimadzu GC-2010 gas chromatograph (GC; Shimadzu Co., Kyoto, Japan). The GC was equipped with a flame ionization detector (FID) and a Teknokroma (TR151035, TRB-FFAP $30 \mathrm{~m} \times 0.53 \mathrm{~mm} \times 0.50 \mu \mathrm{m}$; Teknokroma, Barcelona, Spain) capillary column. Temperatures of injector and detector were 170 and $190{ }^{\circ} \mathrm{C}$, respectively. Helium was used as carrier gas with a flow rate of $1 \mathrm{ml} \cdot \mathrm{min}^{-1}$. 
Faeces and blood were collected at day 14 and placed at $-20{ }^{\circ} \mathrm{C}$ until further analysis. Samples were thawed in a microwave oven, and boron concentration was determined by a Dionex-3000 ion chromatography system (Thermo-Fischer Scientific, Waltham, MA, USA) as described by Vanatta et al. (1999).

\section{Statistical analysis}

Statistical analysis was performed using SPSS 14.01 (SPSS Inc., Chicago, IL, USA). Measurements from the same ram, collected at different times $(0 \mathrm{~h}$ and $3 \mathrm{~h}$ ), were considered as repeated measures in the analysis of variance (ANOVA). The effect of time $\times$ diet was not significant, so only diet effects within each sampling time were reported. Multiple comparisons among means were conducted using Tukey's post-hoc test. Differences were considered significant at $P<0.05$.

\section{Results}

No significant difference was observed in dry matter intake (DMI) among the experimental groups, since there were no residuals between meals in any group. Thereby, total feed intake of rams was recorded as $1400 \mathrm{~g} \cdot \mathrm{d}^{-1}$ in this experiment.

The mean $\mathrm{pH}$ in rumen fluid was 6.86 and 6.19 before and $3 \mathrm{~h}$ after feeding, respectively, and tended to increase $(P=0.059)$ in B1 and B3 groups $3 \mathrm{~h}$ after feeding (Table 2).

The ammonia concentration in rumen fluid tended to be lower $(P=0.076)$ in $\mathrm{B} 1, \mathrm{~B} 2$ and $\mathrm{B} 3$ in comparison with the control but also only $3 \mathrm{~h}$ after feeding (Table 2).

In comparison with control diet, boron supplementation did not increase the total VFA concentration in rumen fluid, however the difference was stated between B1 and B2, B3 groups before and $3 \mathrm{~h}$ after feeding $(P=0.037$ and $P=0.26$, respectively). The molar proportion of acetate was higher in B1 and B2 groups than in control and B3 groups ( $P \leq 0.000$ for both time points), whereas the propionate proportion was the lowest in all three boron-supplemented group $(P \leq 0.000$ for both time points). The acetate:propionate ratio was the lowest in control group and the highest in B1 and $\mathrm{B} 2$ groups before feeding $(P \leq 0.000)$. Three $\mathrm{h}$ after feeding no difference was observed between boronsupplemented groups (B1-B3) which have higher ratio than control group $(P \leq 0.000)$. Only after feeding the iso-butyrate proportion in rumen fluid
Table 2. Effects of diet supplementation with boron on rumen microbial fermentation in yearling rams

\begin{tabular}{|c|c|c|c|c|c|c|}
\hline \multirow{2}{*}{ Indices } & \multicolumn{4}{|c|}{ Experimental diet } & \multirow{2}{*}{$\begin{array}{l}\text { Standarc } \\
\text { error }\end{array}$} & \multirow{2}{*}{${ }^{d}$-value $^{1}$} \\
\hline & control & B1 & B2 & B3 & & \\
\hline \multicolumn{7}{|l|}{$\overline{\mathrm{pH}}$} \\
\hline $\mathrm{Oh}$ & 6.95 & 6.84 & 6.85 & 6.78 & 0.04 & 0.408 \\
\hline $3 \mathrm{~h}$ & 6.11 & 6.40 & 6.06 & 6.20 & 0.05 & 0.059 \\
\hline \multicolumn{7}{|c|}{ Ammonia $\left(\mathrm{NH}_{3}-\mathrm{N}\right), \mathrm{mmol} \cdot \mathrm{l}^{-1}$} \\
\hline $\mathrm{Oh}$ & 401.25 & 283.75 & 376.88 & 363.75 & 10.07 & 0.145 \\
\hline $3 \mathrm{~h}$ & 227.50 & 170.00 & 161.88 & 180.63 & 19.19 & 0.076 \\
\hline
\end{tabular}

Total volatile fatty acids (TVFA), $\mathrm{mmol} \cdot \mathrm{l}^{-1}$

$\begin{array}{ccccccc}0 \mathrm{~h} & 57.94^{\mathrm{ab}} & 55.92^{\mathrm{a}} & 63.37^{\mathrm{ab}} & 74.79^{\mathrm{b}} & 2.69 & 0.037 \\ 3 \mathrm{~h} & 96.12^{\mathrm{ab}} & 85.81^{\mathrm{a}} & 103.58^{\mathrm{b}} & 103.36^{\mathrm{b}} & 2.53 & 0.020\end{array}$

Molar proportions, $\%$ of TVFA

acetate

\begin{tabular}{lllllll}
\hline h & $42.38^{\mathrm{a}}$ & $47.36^{\mathrm{b}}$ & $47.68^{\mathrm{b}}$ & $43.62^{\mathrm{a}}$ & 0.64 & 0.000
\end{tabular}

$\begin{array}{lllllll}3 \mathrm{~h} & 41.47^{\mathrm{a}} & 46.45^{\mathrm{b}} & 46.13^{\mathrm{b}} & 43.31^{\mathrm{a}} & 0.59 & 0.000\end{array}$

propionate

\begin{tabular}{lllllll}
\hline $\mathrm{h}$ & $27.82^{\mathrm{b}}$ & $22.18^{\mathrm{a}}$ & $22.20^{\mathrm{a}}$ & $23.06^{\mathrm{a}}$ & 0.69 & 0.000
\end{tabular}

$\begin{array}{lllllll}3 \mathrm{~h} & 34.03^{\mathrm{b}} & 26.51^{\mathrm{a}} & 27.52^{\mathrm{a}} & 26.58^{\mathrm{a}} & 0.88 & 0.000\end{array}$

iso-butyrate

$\begin{array}{lllllll}0 \mathrm{~h} & 2.60 & 2.52 & 2.49 & 2.50 & 0.07 & 0.961\end{array}$

$\begin{array}{lllllll}3 \mathrm{~h} & 1.01^{\mathrm{a}} & 1.42^{\mathrm{b}} & 1.01^{\mathrm{a}} & 1.45^{\mathrm{b}} & 0.07 & 0.006\end{array}$

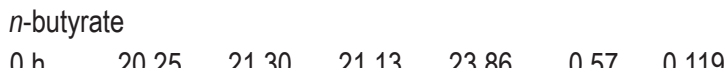

$\begin{array}{lllllll}0 \mathrm{~h} & 20.25 & 21.30 & 21.13 & 23.86 & 0.57 & 0.119 \\ 3 \mathrm{~h} & 18.34^{\mathrm{a}} & 20.40^{\mathrm{ab}} & 20.72^{\mathrm{ab}} & 22.41^{\mathrm{b}} & 0.51 & 0.021\end{array}$

$\begin{array}{llllll}\text { iso-valerate } & & 20.72^{\mathrm{b}} & 22.41 & 0.51 & 0.021\end{array}$

\begin{tabular}{lllllll}
\hline $\mathrm{h}$ & 4.13 & 4.23 & 3.98 & 4.16 & 0.13 & 0.940
\end{tabular}

$\begin{array}{lllllll}3 \mathrm{~h} & 1.20^{\mathrm{ab}} & 1.85^{\mathrm{ab}} & 1.14^{\mathrm{a}} & 1.94^{\mathrm{b}} & 0.13 & 0.017\end{array}$

$n$-valerate

$\begin{array}{lllllll}0 \mathrm{~h} & 2.44^{\mathrm{c}} & 2.05^{\mathrm{ab}} & 1.99^{\mathrm{a}} & 2.33^{\mathrm{cb}} & 0.06 & 0.002 \\ 3 \mathrm{~h} & 3.51^{\mathrm{ab}} & 3.10^{\mathrm{a}} & 3.02^{\mathrm{a}} & 3.87^{\mathrm{b}} & 0.11 & 0.004\end{array}$

$\begin{array}{lllllll}\text { caproate } & & & & & & \\ 0 h & 0.42 & 0.38 & 0.54 & 0.43 & 0.04 & 0.499\end{array}$

$\begin{array}{lllllll}3 \mathrm{~h} & 0.56 & 0.30 & 0.46 & 0.46 & 0.08 & 0.737\end{array}$

Acetate/propionate ratio

$\begin{array}{lllllll}0 \mathrm{~h} & 1.53^{\mathrm{a}} & 2.14^{\mathrm{c}} & 2.16^{\mathrm{c}} & 1.90^{\mathrm{b}} & 0.28 & 0.000\end{array}$

$\begin{array}{lllllll}3 \mathrm{~h} & 1.22^{\mathrm{a}} & 1.76^{\mathrm{b}} & 1.68^{\mathrm{b}} & 1.63^{\mathrm{b}} & 0.06 & 0.000\end{array}$

Protozoan abundance, $\times 10^{3} \cdot \mathrm{I}^{-1}$

$\begin{array}{lllllll}0 \mathrm{~h} & 46.19^{\mathrm{a}} & 82.44^{\mathrm{ab}} & 76.88^{\mathrm{ab}} & 96.88^{\mathrm{b}} & 6.66 & 0.030\end{array}$

$\begin{array}{lllllll}3 \mathrm{~h} & 23.13^{\mathrm{a}} & 50.81^{\mathrm{ab}} & 40.81^{\mathrm{ab}} & 54.88^{\mathrm{b}} & 4.37 & 0.026\end{array}$

${ }_{1}^{1} P$-value - according to one-way ANOVA test; abc - means with different superscripts within each row are significantly different at $P \leq 0.05$ according to Tuckey's post-hoc test

was increased in B1 and B3 in comparison with control and B2 groups after feeding $(P=0.006)$, and $n$-butyrate proportion was higher only in $\mathrm{B} 3$ group in comparison with control group $(P=0.021)$. After feeding the $i s o$-valerate proportion in rumen fluid did not differ between control and boron-supplemented groups, but it was higher in $\mathrm{B} 3$ in comparison with $\mathrm{B} 2$ group $(P=0.017)$. There were statistical differences in the molar proportion of $n$-valerate between the experimental groups both before and after feeding 
( $P=0.002$ and $P=0.004$, respectively). Before feeding the $n$-valerate proportion was lower in B1 and B2 groups than in control group, which did not differ from B3 group. There was also observed difference between B2 and B3 groups. After feeding the control group did not differ from other groups, but the $n$-valerate proportion was higher in B3 in comparison with B1 and B2 group. No change in the molar proportion of caproate was observed.

The obtained results showed (Table 2) significantly higher protozoan abundance in B3 group in comparison with control group before and after feeding ( $P=0.03$ and $P=0.26$, respectively).

Table 3. Boron concentration in the blood serum and plasma, rumen fluid and faeces of yearling rams fed basal diet with or without boron, ppm

\begin{tabular}{|c|c|c|c|c|c|c|}
\hline \multirow{2}{*}{ Indices } & \multicolumn{4}{|c|}{ Experimental diet } & \multirow{2}{*}{$\begin{array}{l}\text { Standard } \\
\text { error }\end{array}$} & \multirow{2}{*}{$P$-value ${ }^{1}$} \\
\hline & control & B1 & B2 & B3 & & \\
\hline Serum & $0.51^{a}$ & $6.81^{b}$ & $9.73^{c}$ & $11.25^{d}$ & 1.06 & $<0.001$ \\
\hline Plasma & $0.20^{\mathrm{a}}$ & $6.91^{\mathrm{b}}$ & $9.92^{\circ}$ & $10.29^{d}$ & 1.05 & $<0.001$ \\
\hline Rumen fluid & $2.48^{\mathrm{a}}$ & $7.31^{\mathrm{b}}$ & $7.36^{\mathrm{b}}$ & $7.29^{b}$ & 0.54 & $<0.001$ \\
\hline Faeces & $8.17^{\mathrm{a}}$ & $16.92^{b}$ & $18.17^{b}$ & $23.74^{\circ}$ & 1.52 & $<0.001$ \\
\hline
\end{tabular}

${ }^{1} P$-value - according to one-way ANOVA test; abcd - means with different superscripts within each row are significantly different at $P \leq 0.05$ according to Tuckey's post-hoc test

The boron concentration in serum and plasma steadily increased with increased dose in the diet $(P \leq 0.000$ for both; Table 3$)$. The rumen fluid concentration of boron reached the concentration of $7.31 \mathrm{ppm}$ after the lowest boric acid dose was added into diet $(P \leq 0.000)$, and the further increasing of the boron dose in the diet did not result in its simultaneous increase in rumen fluid. In the faeces the boron concentration was the highest in B3 group and the lowest in control group $(P \leq 0.000)$.

\section{Discussion}

There is an increasing interest in enhancing the utilization of trace minerals, such as boron, in animal nutrition due to their great economic importance; however, information regarding their effects on rumen fermentation is limited (Yildiz et al., 2013; Sizmaz and Yildiz, 2014). This is the first study to report the effect of boron as a dietary supplement on rumen $\mathrm{pH}$, ammonia and VFA concentrations in ruminants. Data obtained in the presented study clearly demonstrate that boron affects VFA formation, their profile and protozoan abundance in the rumen fluid of rams.
In the present study, rumen $\mathrm{pH}$ (6.06-6.40), which was optimal for microbial growth and activity and fibre digestion (Ørskov and Ryle, 1990), tended to increase in boron-supplemented groups $3 \mathrm{~h}$ after feeding. Lu et al. (2008) have shown that the optimum fibre content influences the cellulolytic activity in the rumen and enhances saliva production. Furthermore, the highest dose of boric acid supplementation $\left(400 \mathrm{mg} \cdot \mathrm{kg}^{-1}\right.$ diet) increased iso-butyrate and iso-valerate content originated from dietary proteins or microbial proteins recycling by deamination and decarboxylation of some amino acids (Miltko et al., 2016) and tended to decrease ammonia concentration in comparison with control group $3 \mathrm{~h}$ after feeding. Theoretically, a higher production of ammonia due to the degradation and fermentation of proteins or peptides and also amino acids such as valine, leucine and isoleucine leads to higher concentrations of iso-butyrate and iso-valerate in the rumen (Mathieu et al., 1996). Additionally, iso-VFAs might increase digestibility of nutrients (especially dry matter) and microbial population in ruminal fluid (Miltko et al., 2016). This difference could be explained by amino acid degradation of dietary crude protein, since amino acids are protected by bacteria associated with rumen protozoa (Deckardt et al., 2016). In the present study, the increased protozoan abundance was observed after the highest dose of boric acid was added into diet, which could result in the reduction of ammonia utilizing bacteria. Since trace minerals form the complexes with protozoa and bacteria (Allen and Gawthornet, 1987), this form could be effective on bioactivity and metabolism by evaluating the degradation. However, further studies are needed to evaluate the effect of boron on the degradation of nutrients, such as fibre and crude protein, in rumen fluid both in vitro and in vivo.

In ruminants, forage-rich diets lead to acetate formation, whereas concentrate-rich diets - to propionate formation (Mc Donald et al., 2010). The basal diet used in the present study was a high forage ration, and any changes in VFA profile could be attributed to the interaction of lactate utilizing bacteria with acetate-propionate utilizing bacteria. Lactate is rapidly converted into propionate, $n$-butyrate, $n$-valerate and caproate in the rumen by lactate utilizing bacteria that use acetate as a co-factor, leading to diverse concentrations of acetate and propionate (Mao et al., 2008; Deckardt et al., 2016). Our data showed that the increasing concentration of boron altered the VFA profile in a dose-dependent manner. In comparison with control group the proportion of acetate increased in $\mathrm{B} 1$ and $\mathrm{B} 2$ groups, $n$-butyrate - 
in $\mathrm{B} 3$ group, iso-butyrate - in B1 and B3 groups and iso-valerate - in $\mathrm{B} 3$ group, whereas the proportion of propionate was lower in all boron-supplemented groups and of $n$-valerate - in B1 and B2 groups. Our results also documented that the supplementation of boric acid to ram diets increased acetateto-propionate ratio in comparison with the control diet. Because increasing of proportion of selected VFA, our investigation might have indicated that the boron from dietary boric acid supplementation can increase the fibre digestion and microbial growth, thereby could have increased the production of acetate coming from bacteria. Further studies are necessary to indicate the effects of boron on lipid metabolism such as fatty acid profile, cholesterol concentration in tissues, since acetate plays a major role in energy production as component of acetyl-coenzyme A (acetyl-CoA).

Our study showed that boron concentrations in the blood and faeces were increasing with the increasing level of boron in the diet. These results are in agreement with previous study of Çinar et al. (2015), who reported a significant linear increase in boron concentration in the blood serum of poultry fed diets supplemented with boron. Additionally, the amount of boron in the faeces increased with the increasing concentration of dietary boron in laying hens (Küçükyilmaz et al., 2014). Higher boron content in the faeces could be explained by its availability and the fact that it is not accumulated in any internal organ. The boron concentration in the rumen fluid was lower than that in the faeces, showing that the retention time of boron in the rumen is probably short, and that the mineral is rapidly absorbed by the gastrointestinal epithelia (Hunt et al., 1997). It should be stressed that in the present study boron concentration in rumen fluid reached the concentration of $7.31 \mathrm{ppm}$ when the boric acid was added at a dose of $200 \mathrm{mg} \cdot \mathrm{kg}^{-1}$ and the further dose increase did not resulted in simultaneous increase of boron content in rumen fluid.

\section{Conclusions}

Dietary boron supplementation had a dose-dependent influence on rumen microbial fermentation and protozoan abundance in yearling rams. However, the boron concentration in rumen fluid did not increased simultaneously with increased dose in a diet. Further studies are needed to estimate the most recommended dose of boron in the ruminant diet and to better understand the boron role in processes occurring in the rumen.

\section{Acknowledgments}

This work was supported by the Turkish Prime Ministry State Planning Organization (Project No. 2003K120190) and the National Boron Research Institute (Project No. 2011Ç0302).

We would like to thank Editage for English language editing.

\section{References}

Allen J.D., Gawthornet J.W., 1987. Involvement of the solid phase of rumen digesta in the interaction between copper, molybdenum and sulphur in sheep. Br. J. Nutr. 58, 265-276, https://doi.org/10.1079/BJN19870094

AOAC International, 1995. Official Methods of Analysis of AOAC International. $16^{\text {th }}$ Edition. Arlington, VA (USA)

Çinar M., Küçükyilmaz K., Bozkurt M., Çatli A.U., Bintaş E., Akşit H., Konak R., Yamaner Ç., Seyrek K., 2015. Effects of dietary boron and phytase supplementation on growth performance and mineral profile of broiler chickens fed on diets adequate or deficient in calcium and phosphorus. Br. Poult. Sci. 56, 576-589, https://doi.org/10.1080/00071668.2015.1079699

Deckardt K., Metzler-Zebeli B.U., Zebeli Q., 2016. Processing barley grain with lactic and tannic acid ameliorates rumen microbial fermentation and degradation of dietary fibre in vitro. J. Sci Food Agric. 96, 223-231, https://doi.org/10.1002/jsfa.7085

Devirian T.A., Volpe S.L., 2003. The physiological effects of dietary boron. Crit. Rev. Food Sci. Nutr. 43, 219-231, https://doi. org/10.1080/10408690390826491

Hunt C.D., Herbel S.L., Nielsen F.H., 1997. Metabolic responses of postmenopausal women to supplemental dietary boron and aluminum during usual and low magnesium intake: boron, calcium and magnesium absorption and retention and blood mineral concentrations. Am. J. Clin. Nutr. 65, 803-813

Kabu M., Uyarlar C., 2015. The effects of borax on milk yield and selected metabolic parameters in Austrian Simmental (Fleckvieh) cows. Vet. Med. 60, 175-180, https://doi. org/10.17221/8104-VETMED

Küçükyilmaz K., Erkek R., Bozkurt M., 2014. The effects of boron supplementation of layer diets varying in calcium and phosphorus concentrations on performance, egg quality, bone strength and mineral constituents of serum, bone and faeces. Br. Poult. Sci. 55, 804-816, https://doi.org/10.1080/0007166 8.2014 .975782

Lu C.D., Kawas J.R., Mahgoub O.G., 2008. Recent advancements in fiber digestion and utilization in goats. Trop. Subtrop. Agroecosyst. 9, 65-72

Mao S.Y., Zhang G., Zhu W.Y., 2008. Effect of disodium fumarate on ruminal metabolism and rumen bacterial communities as revealed by denaturing gradient gel electrophoresis analysis of 16 S ribosomal DNA. Anim. Feed Sci. Technol. 140, 293-306, https://doi.org/10.1016/j.anifeedsci.2007.04.001

Mathieu F., Jouany J.P., Sénaud J., Bohatier J., Bertin G., Mercier M., 1996. The effect of Saccharomyces cerevisiae and Aspergillus oryzae on fermentations in the rumen of faunated and defaunated sheep; protozoal and probiotic interactions. Reprod. Nutr. Dev. 6, 271-287, https://doi.org/10.1051/rnd:19960305

McDonald P., Edwards R.A., Greenhalgh J.F.D., Morgan C.A., Sinclair L.A., Wilkinson G., 2010. Animal Nutrition. $7^{\text {th }}$ Edition. Pearson, Oxford (UK) 
Miltko R., Rozbicka-Wieczorek J.A., Wiesyk E., Czauderna M., 2016. The influence of different chemical forms of selenium added to the diet including carnosic acid, fish oil and rapeseed oil on the formation of volatile fatty acids and methane in the rumen, and fatty acid profiles in the rumen content and muscles of lambs. Acta Vet. Beogr. 66, 373-391, https://doi.org/10.1515/acve-2016-0032

Ogimoto K., Imai S., 1981. Atlas of Rumen Microbiology. Japan Scientific Societies Press, Tokyo (Japan), p. 158

Ørskov E.R., Ryle M., 1990. Energy Nutrition in Ruminants. Elsevier Science Publishers Ltd., Essex (UK)

Rozbicka-Wieczorek A.J., Czauderna M., Więsyk E., Radzik-Rant A., 2016. Selenium species in diet containing carnosic acid, fish and rapeseed oils affect fatty acid profiles in lamb muscles. J. Anim. Feed Sci. 25, 216-225, https://doi.org/10.22358/ jafs/65555/2016

Serbester U., 2013. Determination of boron level in feeds used in cattle nutrition in regions of central Anatolia and mediterranean of Turkey. KSÜ Doğa Bil. Derg. 16, 25-27

Sizmaz Ö., Yildiz G., 2014. Effects of dietary boric acid and ascorbic acid supplementation on performance, some blood and bone parameters in broilers. Kafkas Univ. Vet. Fak. Derg. 20, 55-61
Spears J.W., 2003. Trace mineral bioavailability in ruminants. J. Nutr. 133, Suppl. 1, 1506S-1509S

Tanaka M., Fujiwara T., 2008. Physiological roles and transport mechanisms of boron: perspectives from plants. Pflüg. Arch. Eur. J. Physiol. 456, 671-677, https://doi.org/10.1007/s00424-0070370-8

TSE, 1991. Animal Feeds. Metabolic Energy Determination (Chemical Method). Turkish Standards Institute (TSE), Publication No. 9610, Ankara (Turkey)

WHO, 1998. International Programme on Chemical Safety. Environmental Health Criteria 204: Boron. Geneva (Switzerland), pp. 201

Vanatta L.E., Coleman D.E., Slingsby R.W., 1999. Low-level calibration study for a new ion chromatographic column to determine borate in deionized water. J. Chrom. A 850, 107-117,http:// dx.doi.org/10.1016/S0021-9673(99)00263-0

Yildiz G., Köksal B.H., Sizmaz Ö., 2013. Influence of dietary boric acid and liquid humate inclusion on bone characteristics, growth performance and carcass traits in broiler chickens. Arch. Geflügelk. 77, 260-265 